INTERNATIONAL JOURNAL OF
ORGANIZATIONAL LEADERSHIP
www.AIMIJOURNAL.COM

\title{
To What Extent Trust in Leader and Ethical Climate Affect Turnover Intention? A Research on Private and Public Bank Employees
}

\author{
E. Serra Yurtkoru ${ }^{1}$, SebnemEnsari ${ }^{2}$, Melisa ErdilekKarabay ${ }^{3^{*}}$ \\ ${ }^{1}$ Marmara University, 34180, Istanbul, Turkey \\ ${ }^{2}$ Okan University, 34959, Istanbul, Turkey \\ ${ }^{3}$ Marmara University, 34722, Istanbul, Turkey
}

\begin{abstract}
Keywords:

Ethical Climate, Ethical Leadership, Organisational Justice, Private and Public Banks, Structural Equation Modelling, Trust in Leader, Turnover Intention

\begin{tabular}{l}
\hline Received \\
09 September 2017 \\
Received in revised form \\
25 February 2018 \\
Accepted \\
28 February 2018 \\
\hline
\end{tabular}

Correspondence:

syurtkoru@marmara.edu.tr

Drawing on theory and research, the mediating roles of trust in leader and ethical climate on the relations between ethical leadership, organisational justice, and turnover intention are examined with structural equation modelling. Using 571 private and 535 public bank employees, it is found that turnover intention can be decreased by increasing trust in leader and ethical climate in the environment. In addition, the full mediations of trust in leader and ethical climate are supported in the relations between ethical leadership and turnover. However, trust in leader and ethical climate are found to have partial mediating effects between distributive justice and turnover and it is also found that procedural justice does not have an effect on turnover intention. Moreover, invariance tests have identified both model and structural invariance indicating equivalence across both private and public bank samples.

Employee turnover has been one of the most studied topics in the field of organisational behaviour. One of the important antecedents of turnover intention of employees is leadership (Elçi, Şener, Aksoy, \&Alpkan, 2012). Since ethical leaders take action as role models in the organisation, they develop ethical behaviour among their subordinates (Brown, Treviño, \& Harrison, 2005). If unethical behaviours of senior employees are ignored, other employees'
\end{abstract}


morale and the ethical perceptions will be damaged (Bowie \& Schneider, 2011). In this regard, various consequences of decisions taken by ethical and unethical leaders have revealed the significant effect of ethical leadership on employees, managers and organisations (Toor\&Ofori, 2009). When considering the ethical scandals, the need for ethical leadership has become evident in every organisation (Brown \& Trevino, 2006).

Apart from ethical leadership, organisations should be aware of organisational ethical climate (Kaptein, Huberts, Avelino, \& Lasthuizen, 2005). Last decade showed that corporations are much more employed with establishing an ethical climate for establishing ethical compliance within the organisations (Bowie \& Schneider, 2011). A positive ethical climate providing ethical guidelines will make employees feel good about their job. Employees who desire an ethical climate should be less likely to quit where the climate is perceived as ethical (Mulki, Jaramillo, \& Locander, 2006; Schwepker, 2001).

Organisational justice in the organisation at different levels is critical. Reflection of this fairness to employees' behaviours as an organisational outcome are analysed under the equity theory and lately under the social exchange theory. Both procedural justice and distributive justice are important predictors of work outcomes (Greenberg, 1990).

Supervisor trust or so-called "trust in leader" is therefore highly correlated with employees' turnover intention (Costigan, Insinga, Berman, Kranas, \& Kureshov, 2011). Furthermore, trust is an important matter and strategies for understanding how employees perceive organisational justice and how their reactions affect the organisation are required to monitor and establish high levels of organisational trust (Kickul, Gundry, \& Posig, 2005).

Although a growing number of studies have investigated the predicting factors for turnover intention, the literature presents limited evidence with regard to ethical conduct and intention to quit. To examine this further, we investigated ethical leadership and organisational justice as antecedents of turnover intentions. The study also aims to test the mediating effects of ethical climate and trust in leader in this interaction.

\section{Ethical Leadership and Turnover Intention}

To understand the moral philosophy of leadership, researches address the ethical leadership (Brown \& Trevino, 2006; Resick, Hanges, Dickson, \&Mitchelson, 2006; Walumbwa et al., 2011). In literature, Enderle (1987) was one of the first scholars who used the term of "ethical leadership" under the name of "managerial ethical leadership". Enderle defined managerial ethical leadership as "a type of leadership that takes responsibility during complicated moral situations."

Although the subject of ethical leadership is promising, there are limited studies providing empirical evidence between ethical leadership and employee job outcomes (Toor \& Ofori, 2009). Until now, ethical leadership has been studied as a predictor of job related attitudes and behaviours like organisational commitment (Kim \& Brymer, 2011), organisational citizenship behaviour (Mayer, Aquino, Greenbaum, \& Kuenzi, 2012), organisational voice (Walumbwa \& Schaubroeck, 2009), trust (Arslantaş \& Dursun, 2008; Van den Aker, Heres, Lasthuizen, \& Six, 2009), job performance (Walumbwa et al., 2011), and job satisfaction (Neubert, Carlson, Kacmar, Roberts, \& Chonko, 2009). Ganji and Dalvi (2014) and Palanski, Avey, and Jiraporn (2014) conducted studies to analyse the effects of ethical leadership on turnover intention. The 
results showed that there is a negative correlation between ethical leadership and turnover intention (and job searching behaviours). Similarly, Babalola, Stouten, and Euwema (2016) examined how frequent change interacts with ethical leadership to reduce turnover intentions. The outcome showed that ethical leadership moderated the relationship between frequent change and turnover intention; to this end, the relationship was positive only when ethical leadership was low. So far, the direct effects of ethical leadership on the employee turnover intention with various variables were mentioned. However, as stated, these are the results of a limited number of studies. Therefore, to fill this gap, we seek to examine the relation between the perception of ethical leadership and employees' turnover intention.

\section{Organisational Justice and Turnover Intention}

Moorman (1991) determined organisational justice as the term used to outline the role of fairness as it directly have reference to the workplace. Notably, organizational justice is dealt with the procedures in which employees decide if they are behaved reasonably in their work and the ways in which those determinations affect other work-related variables. Three dimensions of organisational justice explained as distributive justice, procedural justice, and interactional justice in the related literature. Interactional justice is defined as the quality of interpersonal treatment received at the hands of decision makers (Bies\&Moag, 1986). Distributive justice is defined as the perceived fairness of outcomes of employees receives while procedural justice is defined as the perceived fairness of the means used to determine those outcomes (Folger \& Konovsky, 1989).

Literature among organizational justice has long identified the distinction between procedural and interactional justice. Recently, several researchers have proposed that procedural and interactional justice can be explained through social exchange theory (Colquitt et al., 2013; Dussauge, Arslan, \& Wassmer, 2015; Ko \& Hur, 2014). Social exchange theory has become one of the critical paradigms for examining employees' attitudes (DeConinck, 2010) which is defined as "the non-compulsory actions of individuals that are influenced by the returns they are required to bring and commonly do in fact bring from others" (Blau, 1964). Through his conceptualization, Blau (1964) expanded on Homan's (1958) conceptualization of distributive justice and made a significant contribution to justice theory by distinguishing two types of exchanges, namely economic and social. Especially, procedural justice has more connection with the exchange between the individual and employing organization, whereas interactional justice mainly refers to the exchange between the individual and his or her supervisor (Cropanzano, Prehar, \& Chen, 2002).

As examined by previous researchers (Aryee, Budhwar, \& Chen, 2002; Loi, Hang, Yue, \& Foley, 2006), the relation between organisational justice and turnover intention as a work outcome is investigated under the social exchange theory and Adam's (1965) equity theory. The relation between justice and organisational outcomes is explained also under equity theory, which emphasizes employees received outcomes such as pay and promotions based upon their contributions to their organisations. Lately, this relation is analysed under the umbrella of social exchange theory, which supports the idea that if employees believe the organisation treats them fairly, in other words perceive justice by their superior, they supply desirable outcomes (Allen, Shore, \& Griffeth, 2003; Folger \& Konovsky, 1989; Kerman \& Hanges, 
2002; McFarlin\& Sweeney 1992). Ambrose and Schminke (2003) emphasized that distributive justice has closer relation with the economic exchange than social exchange. There are also studies that indicate the relation between organisational justice and turnover intention (Colquitt, Conlon, Wesson, Porter, \& Ng, 2001; Hemdi \& Nasurdin, 2007; Loi et al, 2006; Nadiri \& Tanova, 2010; Ponnu \& Chuah, 2010; Poon, 2012).

\section{Mediating Role of Ethical Climate and Trust in Leader}

Ethical climate informs organisation members about what they can do and what they should do (Victor \& Cullen, 1988). The relationship between ethical climate and employee behaviour is critical because unethical behaviour can be costly to organisations and society (Barsky, 2008). Today, to develop a climate that encourages and supports employees' moral philosophy holds a great importance for organisations. Accordingly, the more the climate of the organisation is perceived ethical the less unethical decision- making will be done. Studies (Grojean, Resick, Dickson, \& Smith 2004; Jaramillo, Mulki, \& Solomon, 2006; Mulki, Jaramillo, \& Locander, 2006; Omar and Ahmad, 2014; Ulrich et al., 2007; Wimbush \& Shepard, 1994) conducted until today often show strong evidence that ethical climate is related to various behaviours in organisations. However, it is observed that most researches have focused on explaining the predictors of an ethical climate rather than the direct or indirect effect of ethical climate on organisational outcomes (Shin, 2012). In this study, we examine whether ethical climate plays a mediating role on ethical leadership, organisational justice, and turnover intention interaction.

Researchers argue that trust is a major determinant of job attitudes and behavioural intentions (Davis, Schoorman, Mayer \& Tan, 2000). Social exchange involves two important facets including trust and fairness. Similar to the justice paradigm discussed above, fair treatment will enhance the social exchange relationship and, thus, will increase the level of trust between the two parties (DeConinck, 2010). While organisational trust has a crucial role on decreasing employees' deviant behaviour in organisations, leader's trust is critical because when there is a high level of trust between managers and co-workers in the workplace, employees have commitment to organisation, high job satisfaction, and a better quality of working life (Demir, 2011). These facts appear as the motives of intention to remain. Therefore, trust is often assumed as an important predictor of turnover intention (Mulki et al., 2006). Yeti the mediating role of ethical climate is examined as a mediator in limited number of studies (Mayer, Kuenzi, \& Greenbaum, 2010; Zehir, Müceldili, Altindağ, Şehitoğlu, \& Zehir, 2014; Elçi, Karabay, \& Akyüz, 2015).

Numerous researches have highlighted the important link between leadership behaviour and trust within organisations (Dirks \& Ferrin, 2002; Gillespie \& Mann 2004; Gomez \& Rosen, 2001; Joseph \& Winston 2005; Jung \& Avolio 2000; Mayer, Davis, \& Schoorman, 1995; Podsakoff, MacKenzie, Moorman, \& Fetter, 1990). However, a few number of studies specifically addresses the correlational link between ethical leadership behaviours and followers' trust in their leaders. Van den Akker et al. (2009) investigated the relationship between ethical leadership behaviours and trust. Findings showed that ethical leader behaviours were significantly related to employees' trust in their manager. They also indicated that the more a leader behaves in a way that followers experience is the suitable ethical leader behaviour, the more a leader will deserve trust. However, when the mediating role of trust is 
considered, the literature has a limited number of evidence (Aryee, Budhwar, \& Chen, 2002; Mulki et al., 2006; Chan, Huang, \& Ng, 2008).

There are very clear differences regarding employment between public and private sectors in Turkey from the stage of hiring until the stage of leaving the job. As a result of these, many studies reveal that, employees' perceptions of organisational justice, job satisfaction, and organisation commitment are significantly lower in public sector than private sector. Furthermore, the intention to leave the job is also expected less in public sector than private sector since having a job in private sector requires much complicated process. This affects employees' intention to quit. In this sense, the conceptual model presented above could be different between sectors. Therefore, to examine the effect of sector on the conceptual model, invariance test is applied.

\section{The Study}

The main goal of this research is to examine the mediating roles of trust in leader and ethical climate on the relations between ethical leadership, organisational justice, and turnover intention. Therefore, the following hypotheses guided the study:

$\mathbf{H}_{1}$ : Ethical leadership has a negative effect on turnover intention.

$\mathbf{H}_{2 \mathbf{a}}$ : Procedural justice has a negative effect on turnover intention.

$\mathbf{H}_{\mathbf{2 b}}$ : Distributional justice has a negative effect on turnover intention.

$\mathbf{H}_{3}$ : Ethical climate mediates the relationship between ethical leadership and turnover intention.

$\mathbf{H}_{4}$ : Ethical climate mediates the relationship between procedural justice and turnover intention.

$\mathbf{H}_{5}$ : Ethical climate mediates the relationship between distributive justice and turnover intention.

$\mathbf{H}_{6}$ : Trust in leader mediates the relationship between ethical leadership and turnover intention.

$\mathbf{H}_{7}$ : Trust in leader mediates the relationship between procedural justice and turnover intention.

$\mathbf{H}_{\mathbf{8}}$ : Trust in leader mediates the relationship between distributive justice and turnover intention.

We explore the above-mentioned hypotheses by empirically testing our conceptual model as presented in Figure 1.

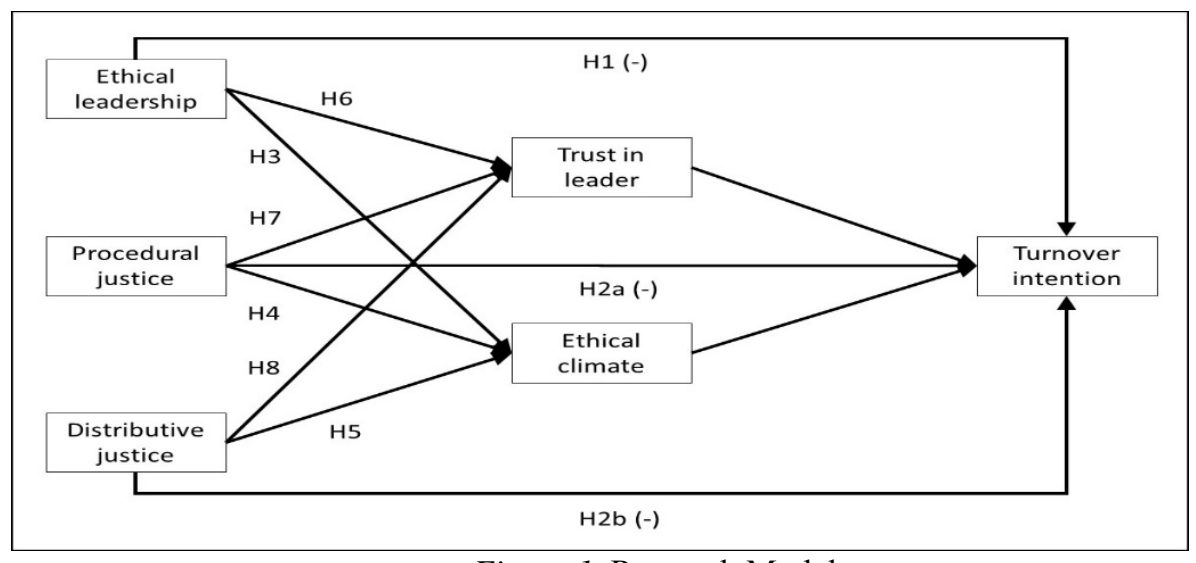

Figure 1. Research Model 


\section{Method}

\section{Sample and Measures}

Data for this study are collected from financial sector, particularly from commercial banks located in Istanbul. Following this, 1500 questionnaires were distributed among bank employees (particularly, 750 in private and 750 in public banks). A sample of 1106 respondents was obtained with a $74 \%$ return rate. As a result, research sample consists of 571 white-collar employees of private banks and 535 white-collar employees from public banks, currently working in various branches. Gender distribution of private sector data is $55.3 \%$ women and $44.7 \%$ men and public sector data is $32.3 \%$ women and $67.7 \%$ men. Age of the samples ranged between 18 to 60 with a mean of 29.5 and a standard deviation of 6.3 , and 18 to 55 with a mean of 29.2 and a standard deviation of 5.4, respectively. Respondents in both samples were highly educated with $89.9 \%$ and $92.0 \%$ university graduates.

A multi-item questionnaire is used in the current study. All the constructs are adopted from prior studies and measured using five-point interval scale ranging from ' $1=$ strongly disagree,' to ' $5=$ strongly agree.' Turnover intention is measured with three items adapted from Mobley, Griffeth, Hand, and Meglino (1979). Ethical leadership is measured using Brown et al.'s (2005) ten-item scale. To measure the justice perceptions of respondents, procedural (five items) and distributive justice (five items) scales of Niehoff and Moorman (1993) are used. The ethical climate is measured by Schwepker's (2001) scale, and lastly employees' trust in leader is measured by Rich's (1997) scale.

\section{Results}

\section{Measurement Validation}

To assess the reliability and validity of the measures, CFA are applied to all used scales. Since this study aims to test the theoretical model in public and private sector, prior to CFA, data collected from both sectors are examined to find whether these data could be analysed as separate groups or they should be pooled and further analysed based on single-group. Therefore, test of equality of covariance matrices is performed which indicated nonequivalence of the groups (Box's $\mathrm{M}=2598.45, \mathrm{~F}=4.49, \mathrm{p}=0.00$.). Thus, data are analysed as separate groups.

CFA results showed that all factor loadings are relatively high and remarkable supplying evidence for convergent validity (Bagozzi \& Yi, 1988) in both private and public sector samples. Only two items one from distributive justice and one from ethical climate scales indicated model misspecification, based on the standardized residuals, which is also supported by their modification indices in both samples: Therefore, these items are eliminated. The various fit indices for the CFA suggested good fit to the private sector data set $\chi^{2}(480$, $\mathrm{N}=571)=1913.71, \mathrm{p}=.00$, TLI $=0.90, \mathrm{CFI}=0.91$, RMSEA=0.07) and public sector data set $\left.\chi^{2}(480, \mathrm{~N}=535)=1145.59, \mathrm{p}=.00, \mathrm{TLI}=0.94, \mathrm{CFI}=0.94, \mathrm{RMSEA}=0.05\right)$.

Construct reliabilities of scales, which lied between 0.85 and 0.94 , indicated high internal consistency of the dimensions (Hair, Black, Babin, \& Anderson, 2010; Netemeyer, Bearden, \& Sharma, 2003). Average Variance Extracted (AVE) values were all above 0.50 threshold (Fornell \& Larcker, 1981). To assess the discriminant validity of the scales we first checked the 
Fornell and Larcker (1981) criterion. Then we constrained parameter estimate for the two constructs to unity and compared with factor model where parameter is freely estimated (Anderson \& Gerbing, 1988). Findings of reliability, convergent validity, and discriminant validity satisfied psychometric property requirements for both data sets (See Table 1).

Table 1 shows the confirmatory analysis of constructs.

Table 1

Confirmatory Analysis of Constructs

\begin{tabular}{lcccc}
\hline & \multicolumn{2}{c}{ Private Sector } & \multicolumn{2}{c}{ Public Sector } \\
\cline { 2 - 5 } \multicolumn{1}{c}{ Constructs } & CR & AVE & CR & AVE \\
\hline Turnover intention & 0.90 & 0.75 & 0.86 & 0.68 \\
Trust in leader & 0.94 & 0.75 & 0.90 & 0.64 \\
Ethical leadership & 0.93 & 0.59 & 0.92 & 0.55 \\
Ethical climate & 0.94 & 0.72 & 0.91 & 0.62 \\
Procedural justice & 0.91 & 0.66 & 0.89 & 0.63 \\
Distributive justice & 0.90 & 0.70 & 0.85 & 0.59 \\
\hline
\end{tabular}

Private $\chi^{2}(480, \mathrm{~N}=571)=1913.71, \mathrm{p}=.00, \mathrm{TLI}=.90, \mathrm{CFI}=.91, \mathrm{RMSEA}=.07$

Public $\chi^{2}(480, \mathrm{~N}=535)=1145.59, \mathrm{p}=.00, \mathrm{TLI}=.94, \mathrm{CFI}=.94, \mathrm{RMSEA}=.05$

$\mathrm{CR}=$ Construct Reliability; $\mathrm{AVE}=$ Average variance extracted

Even though data are analysed as separate groups based on test of equality of covariance matrices, and although this test appears to be reasonable, contradictory findings may be found in other tests (Byrne, 2010). Hence, after each sample is tested separately, a multi-group invariance test is applied as well to analyse equivalence of measurements.

In this study, $\triangle$ CFI is used to compare competitive nested models (Cheung \& Rensvold, 2002), where the recommended cut off criterion is $\Delta \mathrm{CFI}=0.01$. The $\Delta \mathrm{CFI}$ finding $(\Delta \mathrm{CFI}=0.00)$, together with the values of the fit indices indicating fit of the model ( $\mathrm{CFI}=0.92$, TLI $=0.91$, RMSEA $=0.04$ ) supported metric invariance. Likewise, invariance of the item intercepts across the samples did not show a significant decrease in fit, $\Delta \mathrm{CFI}=0.00,<0.01$. Furthermore, we tested invariance of covariance variance, where again invariance is supported, $\Delta \mathrm{CFI}=0.00,<$ 0.01 (See Table 2).

As a summary, we achieved configural, metric, and scalar invariance, which satisfies the minimum requirement to say the scales we used in this study, yield equivalent representation among the two sample groups. We also achieved factor covariance invariance, which indicates constructs are related to each other similarly across groups. Hence, we can accept that we reached invariance for our measurement scales and that constructs are perceived and used in similar manner for both private and public sector.

Table 2 presents the goodness of fit statistics for tests of multi-group measurement model invariance. 
Table 2

Goodness of Fit Statistics for Tests of Multi-group Measurement Model Invariance

\begin{tabular}{|c|c|c|c|c|c|c|c|}
\hline Model Description & $\chi^{2}(\mathrm{df})$ & $\Delta \chi^{2}(\Delta \mathrm{df})$ & CFI & $\Delta \mathrm{CFI}$ & TLI & RMSEA & Decision \\
\hline $\begin{array}{l}\text { Configural Invariance } \\
\text { (Unconstraint Model) }\end{array}$ & $3059.31(960) * * *$ & - & 0.92 & - & 0.91 & 0.04 & - \\
\hline $\begin{array}{l}\text { Metric Invariance } \\
\text { (All Factor Loadings } \\
\text { Constraint Equal) }\end{array}$ & $3158.37(987)^{* * *}$ & $99.07(27) * * *$ & 0.92 & -0.00 & 0.91 & 0.04 & Accept Invariance \\
\hline $\begin{array}{l}\text { Scalar Invariance (Variable } \\
\text { Intercepts Constraint Equal) }\end{array}$ & $3449.59(1020) * * *$ & $291.22(33) * * *$ & 0.91 & -0.00 & 0.91 & 0.04 & Accept Invariance \\
\hline $\begin{array}{l}\text { Factor Variance Covariance } \\
\text { Invariance }\end{array}$ & $3562.10(1041) * * *$ & $112.51(21) * * *$ & 0.91 & -0.00 & 0.91 & 0.04 & Accept Invariance \\
\hline $\begin{array}{l}\text { Error Variance Invariance } \\
\text { (Measurement Residuals) }\end{array}$ & $4745.64(1074) * * *$ & $1183.55(33) * * *$ & 0.86 & 0.04 & 0.87 & 0.05 & Reject Invariance \\
\hline
\end{tabular}

Table 3 exhibits the means, standard deviations, Cronbach's alphas and correlations of private sector (left - lower corner) and public sector (right - upper corner) samples.

Table 3

Means, Standard Deviations, Cronbach's Alphas and Correlations of Private Sector (Left - Lower Corner) and Public Sector (Right - Upper Corner) Samples

\begin{tabular}{cccccccccccccc}
\hline & \multicolumn{10}{c}{ Private Sector } & \multicolumn{10}{c}{ Public Sector } \\
\cline { 2 - 15 } Variables & $\mathrm{M}$ & $\mathrm{SD}$ & $\alpha$ & $\mathrm{M}$ & $\mathrm{SD}$ & $\alpha$ & 1 & 2 & 3 & 4 & 5 & 6 \\
\hline 1. Ethical Leader & 3.79 & 0.83 & 0.93 & 3.23 & 0.97 & 0.92 & - & $0.63^{* *}$ & $0.52^{* *}$ & $0.55^{* *}$ & $0.73^{* *}$ & $-0.27^{* *}$ \\
2. Procedural jst & 3.50 & 0.94 & 0.90 & 2.86 & 1.06 & 0.91 & $0.71^{* *}$ & - & $0.59^{* *}$ & $0.47^{* *}$ & $0.69^{* *}$ & $-0.17^{* *}$ \\
3. Distributive jst & 3.18 & 1.07 & 0.90 & 2.84 & 1.10 & 0.89 & $0.52^{* *}$ & $0.56^{* *}$ & - & $0.42^{* *}$ & $0.57^{* *}$ & $-0.21^{* *}$ \\
4. Ethical Climate & 3.95 & 0.96 & 0.94 & 3.34 & 1.07 & 0.84 & $0.52^{* *}$ & $0.47^{* *}$ & $0.43^{* *}$ & - & $0.53^{* *}$ & $-0.20^{* *}$ \\
5. Trust in Leader & 3.71 & 1.03 & 0.94 & 3.20 & 1.11 & 0.90 & $0.80^{* *}$ & $0.73^{* *}$ & $0.51^{* *}$ & $0.46^{* *}$ & - & $-0.28^{* *}$ \\
6. Turnover int & 2.46 & 1.21 & 0.90 & 2.60 & 1.21 & 0.86 & $-0.36^{* *}$ & $-0.40^{* *}$ & $-0.38^{* *}$ & $-0.47^{* *}$ & $-0.36^{* *}$ & - \\
\hline
\end{tabular}

$* \mathrm{p} \leq .05, * * \mathrm{p} \leq .01, * * * \mathrm{p} \leq .001$

Means standard deviations and correlations are provided in Table 3. As expected correlations with turnover intentions were all negative and significant even though their magnitudes were low or moderate. Other variables were significant and positively correlated. When the means are compared between private and public sector, it is seen that all variables were significantly different $\left(\mathrm{t}_{\text {Ethical leadership }}=10.26, \mathrm{p}=0.04, t\right.$ Procedural justice $=10.53, \mathrm{p}=0.00$, $\mathrm{t}_{\text {Distributive justice }}=5.27, \mathrm{p}=0.00, \mathrm{t}_{\text {Ethical climate }}=10.04, \mathrm{p}=0.00, \mathrm{t}_{\text {Trust in leader }}=7.97, \mathrm{p}=0.00, \mathrm{t}_{\text {Turnover }}$ intention $=-1.99, \mathrm{p}=0.00$ ). Except turnover intention, for all variables, mean values were higher in private sector.

\section{Structural Model}

After the validation and invariance test of measurement model, the hypothesized model is tested. Here again an invariance testing strategy is applied to test the replicability of a full structural equation model across private and public sector data (Hair et al., 2010). The structural model results of the both groups indicated good fit to the data (private sector: $\mathrm{CFI}=0.91$, TLI $=0.91$, RMSEA $=0.07$, and public sector: $\mathrm{CFI}=0.94, \mathrm{TLI}=0.94, \mathrm{RMSEA}=0.05$ ). As expected path loadings showed some differences and distributional justice had positive effect on trust in leader in public sector $(\beta=0.32, p=0.00)$; however, this relation was not 
significant in private sector. Likewise, trust in leader had negative effect on turnover intention in public sector $(\beta=-0.26, p=0.00)$ but was not significant in private sector. Procedural justice and distributive justice had negative effect on turnover intention in private sector $(\beta=-0.17$, $p=0.00, \beta=-0.16, p=0.00$, respectively). However in public sector only procedural justice had significant effect on turnover intention $(\beta=0.20, \mathrm{p}=0.00)$ and distributive justice did not significantly explain turnover intention.

Then to test for the moderating effect of sectors, structural model invariance is assessed by imposing cross-group equality constraints on factor loadings and structural path loadings in the private and public sector samples (See Table 4). Whilst separate data tests showed some differences in path loadings, structural invariance identified that the relationships between the constructs were equivalent across both samples (invariance for measurement weights $\Delta \mathrm{CFI}=0.00<0.01$, structural weights $\Delta \mathrm{CFI}=0.00<0.01$, covariances $\Delta \mathrm{CFI}=0.00<0.01$, and residuals $\Delta \mathrm{CFI}=0.00<0.01$ ).

Table 4 illustrated the goodness of fit statistics for tests of multi-group structural model invariance.

Table 4

Goodness of Fit Statistics for Tests of Multi-Group Structural Model Invariance

\begin{tabular}{lccccccc}
\hline Model Description & $\chi^{2}(\mathrm{df})$ & $\Delta \chi^{2}(\Delta \mathrm{df})$ & CFI & $\Delta$ CFI & TLI & RMSEA & Decision \\
\hline Separate Groups & & & & & & & \\
$\quad$ Private Sector & $1914.15(481)^{* * *}$ & - & 0.91 & - & 0.90 & 0.07 & - \\
$\quad$ Public Sector & $1149.68(481)^{* * *}$ & - & 0.94 & - & 0.93 & 0.05 & - \\
Unconstraint Model & $3063.79(962)^{* * *}$ & - & 0.92 & - & 0.91 & 0.04 & - \\
Measurement Weights & $3162.51(989)^{* * *}$ & $98.72(27)^{* * *}$ & 0.92 & -0.00 & 0.91 & 0.04 & Accept Invariance \\
Structural Weights & $3234.45(1000)^{* * *}$ & $71.94(11)^{* * *}$ & 0.92 & -0.00 & 0.91 & 0.04 & Accept Invariance \\
Structural Covariances & $3262.81(1006)^{* * *}$ & $28.36(6)^{* * *}$ & 0.91 & -0.00 & 0.91 & 0.04 & Accept Invariance \\
Structural Residuals & $3270.05(1009)^{* * *}$ & $7.24(3)^{* * *}$ & 0.91 & -0.00 & 0.91 & 0.05 & Accept Invariance \\
Measurement Residuals & $4455.33(1042)^{* * *}$ & $1185.28(33)^{* * *}$ & 0.88 & -0.04 & 0.87 & 0.15 & Reject Invariance \\
\hline$* \mathrm{p} \leq .05 ; * * \mathrm{p} \leq .01 \mid * * * \mathrm{p} \leq .001$ & & & & & & &
\end{tabular}

Figure 2 represents thestructural model estimated (standardized coefficients for initial and second model).

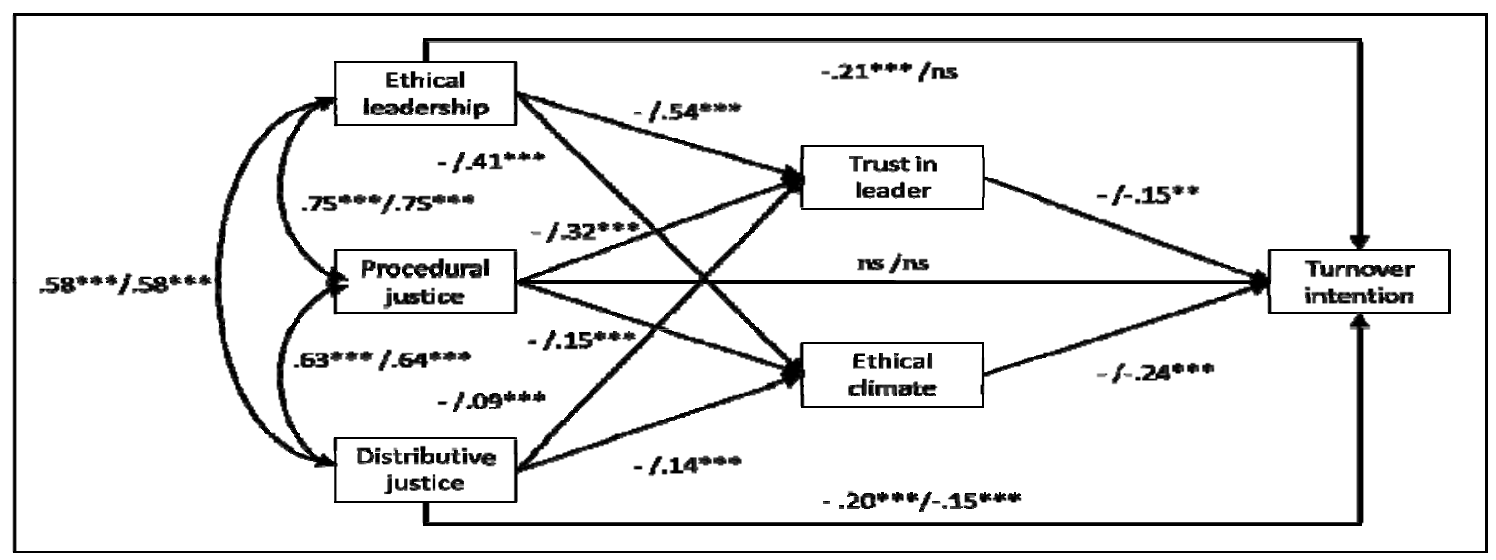

Figure 2. Structural model estimated (standardized coefficients for initial and second model)

Since the analyses revealed that there was invariance across sectors, mediation tests are conducted on combined data set (See Figure 2). Initial model with only the direct effects of 
ethical leadership, procedural and distributive justice on turnover intention had good fit to the data set $\left(\chi^{2}(203, \mathrm{~N}=1106)=921.79, \mathrm{p}=0.00, \mathrm{TLI}=0.95, \mathrm{CFI}=0.96, \mathrm{RMSEA}=0.06\right)$. Findings indicated that procedural justice did not have significant effect on turnover intention, whereas distributional justice and ethical leadership had negative yet low effect on turnover intention ( $\beta=-.21, p=.00, \beta=-.20, p=.00$, respectively). Then a second model is estimated adding mediating variables, trust in leader and ethical climate. The second model showed good fit as well $\left(\chi^{2}(481, \mathrm{~N}=1106)=1902.63, \mathrm{p}=0.00, \mathrm{TLI}=0.94, \mathrm{CFI}=0.95, \mathrm{RMSEA}=0.05\right)$. Both mediating variables had significant however low effect on turnover intention $(\beta=-.15, p=.00, \beta=-.24$, $\mathrm{p}=.00$, respectively). Structural model estimates can be seen from Figure 2 comparatively. Turnover intention can be decreased by increasing trust in leader and ethical climate in the environment. The path between ethical leadership to turnover became insignificant in the second model whilst it was significant in the initial model, full mediation of trust in leader, and ethical climate are supported. However, the path between distributive justice, and turnover intention remained significant yet its effect reduced therefore, mediation of trust in leader and ethical climate were partial.

\section{Discussion and Conclusion}

In the literature, there are numerous researches based on ethical leadership, organisational justice, ethical climate, and turnover intention. Despite the number of studies examining the relationship between employee behaviour and intention to leave, the literature does not provide enough evidence on the effect of employees' perceptions of ethical leadership and justice on their withdrawal behaviours. Therefore, this study aims to analyse ethical leadership and organisational justice as antecedents of turnover intention of employees as well as the mediating effects of ethical climate and trust in leader in this relation.

The study was conducted on employees from public and private banks in Turkish financial sector. The empirical results revealed that both ethical leadership and distributional justice have negative effects on turnover intention where our findings verify the recent findings of Babalola et al. (2016) and Ganji and Dalvi's (2014). However, the effect sizes were not strong as expected. Controversy to the studies of Colquitt et al. (2001) and Loi et al. (2006), hypothesis was partially supported in this study, since procedural justice did not have a significant effect on turnover intention. This may be a consequence of banking sector in Turkey as the industry is well established on procedural structure in general. As a result, employees' justice perceptions related to the procedures may not affect their intention to leave.

As various studies revealed the effect of both procedural and distributive justice on employees' turnover intention, yet, there are studies which indicate only the significant effect of distributive justice (Fields, Pang, \& Chiu. 2000). Supporting the findings of previous studies, results confirmed the significant effect of ethical climate on turnover intention (Deconinck, Deconinck, \& Banerjee, 2013; Hart, 2005; Mulki, Jaramillo, 2008; Stewart, Volpone, Avery, \& MacKay, 2011). Furthermore, the full mediating effect of ethical climate on the relationship between ethical leadership and turnover intention is supported. This finding is one of the major contributions of the study. 
From employees' point of view, ethical leaders act as a role model in ethical issues in organisations. Therefore, our result supports the theoretical assumption that establishing an ethical climate within an organisation depends highly on leader's ethical understanding. This indicates that perception of ethical climate within the organisation could reduce the intention to quit. Results also confirmed that ethical climate partially mediated the relationship between distributive justice and turnover intention, which means distributive justice has both direct and indirect effect through ethical climate on turnover intention. However, the mediating role of ethical climate on procedural justice turnover intention relation was not supported.

The study also tested whether trust in leader mediated the relationship between ethical leadership and turnover intention. The findings indicated the full mediation of trust in leader on relationship between ethical leadership and turnover intention. This is also supported by the literature that asserts the influence of employees' trust in leader on their withdrawal behaviour. When employees have confidence in their leaders, then they may not have strong intention to leave their jobs. Trusted leader can reduce negative attitudes and behaviours by creating a harmonious environment within the organisation. Another finding illustrates the partial mediating effect of trust in leader on distributive justice and turnover intention relation. This finding is in line with the study of Aryee et al. (2002) which also showed the partial effect of trust in leader on both procedural justice and turnover intention and distributive justice and turnover intention relation. However, in this study, no significant mediating effect of trust in leader is found, as there is no significant direct effect of procedural justice on turnover intention.

This study is based on the argument that employees' perceptions of the ethical leadership and justice on their turnover intention could distinguish between public and private banks. In this respect, mean values were higher in all constructs (ethical leadership, procedural and distributive justice, ethical climate, and trust in leader) in private bank employees than public bank employees, whereas turnover intention appears higher in public bank employees compared to private bank employees. However, when the research model is tested, even though separate data tests showed some differences, structural invariance identified that the relationships between the constructs were equivalent in private and public banks.

One of the major contributions of this study is that we present evidence on the mediating effects of both trust in leader and ethical climate on relation between ethical leadership and turnover intention on the field of business and organisational behaviour. Overall, the study also provides insight within banking industry, which has not been analysed enough in previous empirical studies.

This study also has some limitations. First, since data involves respondents from deposit banks, it can be recommended that to present a more detailed industrial analysis, study can be expanded to include other financial institutions such as participation and investment banks and other intermediaries. In addition, the research could be conducted on other industries. The study particularly included data from Turkish banking industry, therefore, the results reflect the characteristics of Turkish banking environment. To increase the generalizability, the model should be examined in other cultures. 


\section{References}

Adams, J. S. (1965). Inequity in social exchange. Advances in Experimental Social Psychology, 2, 267-299.

Allen, D. G., Shore, L. M., \& Griffeth, R. W. (2003). The role of perceived organisational support and supportive human resource practices in the turnover process. Journal of Management, 29(1), 99-118.

Ambrose, M. L., \& Schminke, M. (2003). Organization structure as a moderator of the relationship between procedural justice, interactional justice, perceived organizational support, and supervisory trust. Journal of Applied Psychology, 88(2), 295305.

Anderson, J. C., \& Gerbing, D. W. (1988). Structural equation modeling in practice: A review and recommended two-step approach, Psychological Bulletin, 103, 411-423.

Arslantas, C., \& Dursun, M. (2008). The impact of ethical leadership behavior on trustin manager and psychological empowerment: The mediating role of interactional justice. Anadolu University Journal of Social Sciences, 8(1), 111-128.

Aryee, S., Budhwar, P. S., \& Chen, Z. X. (2002). Trust as a mediator of the relationship between organizational justice and work outcomes: Test of a social exchange model. Journal of organizational Behavior, 23(3), 267-285.

Babalola, M. T., Stouten, J., \& Euwema, M. (2016). Frequent change and turnover intention: The moderating role of ethical leadership. Journal of Business Ethics, 134(2), 311-322.

Bagozzi R. P., \& Yi, Y. (1988). On the evaluation of structural equation models. Journal of the Academy of Marketing Science, 16(1), 74-94.

Barsky, A. (2008). Understanding the ethical cost of organizational goal-setting: A review and theory development. Journal of Business Ethics, 81(1), 63-81.

Bies, R. J., \& Moag, J. S. (1986). Interactional justice: The management or moral outrage. Research in Organizational Behavior, 9, 289-319.

Blau, P. M. (1964). Exchange and power in social life. USA: Transaction Publishers.

Bowie, N. E., \& Schnieder, M. (2011). Business ethics for dummies. NJ: John Wiley \& Sons.

Brown, M. E., Treviño, L. K., \& Harrison, D. A. (2005). Ethical leadership: A social learning perspective for construct development and testing. Organizational Behavior\& Human Decision Processes, 97(2), 117-134.

Brown, M. E., \& Trevino L. (2006). Ethical leadership: A review and future directions. The Leadership Quarterly, 17(6), 595616.

Byrne, B. M. (2010). Structural equation modelling with AMOS: Basic concepts, applications, and programming (2 $2^{\text {nd }}$ ed.). New York, NY: Routledge Taylor \& Francis Group.

Chan, K. W., Huang, X., \& Ng, P. M. (2008). Managers' conflict management styles and employee attitudinal outcomes: The mediating role of trust. Asia Pacific Journal of Management, 25(2), 277-295.

Cheung, G. W, \& Rensvold, R. B. (2002). Evaluating goodness-of-fit indexes for testing measurement invariance. Structural Equation Modeling, 9(2), 233-255.

Colquitt, J. A., Conlon, D. E., Wesson, M. J., Porter, C. O., \& Ng, K. Y. (2001). Justice at the millennium: A meta-analytic review of 25 years of organizational justice research. Journal of Applied Psychology, 86(3), 425-445.

Colquitt, J. A., Scott, B. A., Rodell, J. B., Long, D. M., Zapata, C. P., Conlon, D. E., \& Wesson, M. J. (2013). Justice at the millennium, a decade later: A meta-analytic test of social exchange and affect-based perspectives. Journal of Applied Psychology, 98, 199-236.

Costigan, R. D., Insinga, R. C., Berman, J. J., Kranas, G., \& Kureshov, V. A. (2011). Revisiting the relationship of supervisor trust and CEO trust to turnover intentions: A three-country comparative study. Journal of World Business, 46(1), 74-83.

Cropanzano, R., Prehar, C. A., \& Chen, P. Y. (2002). Using social exchange theory to distinguish procedural from interactional justice. Group \& Organization Management, 27(3), 324-351.

Davis, J. H., Schoorman, F. D., Mayer, R. C., \& Tan, H. H. (2000). The trusted general manager and business unit performance: Empirical evidence of a competitive advantage. Strategic Management Journal, 21(5), 563-576.

DeConinck, J. B. (2010). The effect of organizational justice, perceived organizational support, and perceived supervisor support on marketing employees' level of trust. Journal of Business Research, 63(12), 1349-1355.

DeConinck, J., DeConinck, M. B., \& Banerjee, D. (2013). Outcomes of an ethical work climate among salespeople. International Journal of Business Administration, 4(4), 1-8.

Demir, M. (2011). Effects of organizational justice, trust and commitment on employees' deviant behavior. Anatolia, 22(2), 204-221. 
Dirks, K. T., \& Ferrin, D. L. (2002). Trust in leadership: Meta-analytic findings and implications for research and practice. Journal of Applied Psychology, 87(4), 611-628.

Dussauge, P., Arslan, B., \& Wassmer, U. (2015). Distributive Justice and joint venture termination: A social exchange perspective (No. 1139). HEC Paris.

Elçi, M., Karabay, M. E., \& Akyüz, B. (2015). Investigating the mediating effect of ethical climate on organizational justice and burnout: A study on financial sector. Procedia-Social \&Behavioral Sciences, 207, 587-597.

Elçi, M., Şener, İ., Aksoy, S., \& Alpkan, L. (2012). The impact of ethical leadership and leadership effectiveness on employees' turnover intention: The mediating role of work related stress. Procedia-Social \&Behavioral Sciences, 58, 289297.

Enderle, G. (1987). Some perspectives of managerial ethical leadership. Journal of Business Ethics, 6(8), 657-663.

Fields, D., Pang, M., \& Chiu, C. (2000). Distributive and procedural justice as predictors of employee outcomes in Hong Kong. Journal of Organizational Behavior, 21(5), 547-562.

Folger, R., \& Konovsky, M. A. (1989). Effects of procedural and distributive justice on reactions to pay raise decisions. Academy of Management Journal, 32(1), 115-130.

Fornell, C., \& Larcker, F. D. (1981). Evaluating structural equation models with unobservable variables and measurement error. Journal of Marketing Research, 18(1), 39-50.

Ganji, M., \& Dalvi, M. (2014). The impact of ethical leadership on job stress and occupation turnover intention in nurses of hospitals affiliated to Shahrekord University of Medical Sciences. Journal of Shahrekord University of Medical Sciences, 16(1), 121-128.

Gillespie, N. A., \& Mann, L. (2004). Transformational leadership and shared values: The building blocks of trust. Journal of Managerial Psychology, 19(6), 588-607.

Gómez, C., \& Rosen, B. (2001). The leader-member exchange as a link between managerial trust and employee empowerment. Group \& Organization Management, 26(1), 53-69.

Greenberg, J. (1990). Organizational justice: Yesterday, today, and tomorrow. Journal of Management, 16(2), $399-432$.

Grojean, M. W., Resick, C. J., Dickson, M. W., \& Smith, D. B. (2004). Leaders, values, and organizational climate: Examining leadership strategies for establishing an organizational climate regarding ethics. Journal of Business Ethics, 55(3), $223-241$.

Hair Jr., F. J., Black, C. W., Babin, J. B., \& Anderson, E. R. (2010). Multivariate data analysis: A global perspective (7 $7^{\text {th }}$ ed.). Upper Saddle River, NJ: Prentice Hall Inc.

Hart, S. E. (2005). Hospital ethical climates and registered nurses' turnover intentions. Journal of Nursing Scholarship, 37(2), $173-177$.

Hemdi, M. A., \& Nasurdin, A. M. (2007). Investigating the influence of organizational justice on hotel employees' organizational citizenship behavior intentions and turnover intentions. Journal of Human Resources in Hospitality \& Tourism, 7(1), 1-23.

Homans, G. C. (1958). Social behavior as exchange. American journal of sociology, 63(6), 597-606.

Jaramillo, F., Mulki, J. P., \& Solomon, P. (2006). The role of ethical climate on salesperson's role stress, job attitudes, turnover intention, and job performance. Journal of Personal Selling \& Sales Management, 26(3), 271-282.

Joseph, E. E., \& Winston, B. E. (2005). A correlation of servant leadership, leader trust, and organizational trust. Leadership \& Organization Development Journal, 26(1), 6-22.

Jung, D. I., \& Avolio, B. J. (2000). Opening the black box: An experimental investigation of the mediating effects of trust and value congruence on transformational and transactional leadership. Journal of Organizational Behavior, 21(8), 949-964.

Kaptein, M., Huberts, L., Avelino, S., \& Lasthuizen, K. (2005). Demonstrating ethical leadership by measuring ethics: A survey of US public servants. Public Integrity, 7(4), 299-311.

Kerman, M., \& Hanges, P. (2002). Survivor reactions to reorganization: Antecedents and consequences of procedural, interpersonal, and informational justice. Journal of Applied Psychology, 87, 916-928.

Kickul, J., Gundry, L. K., \& Posig, M. (2005). Does trust matter? The relationship between equity sensitivity and perceivedorganizational justice. Journal of Business Ethics, 56, 205-218

Kim, W. G., \& Brymer, R. A. (2011). The effects of ethical leadership on manager job satisfaction, commitment, behavioral outcomes, and firm performance. International Journal of Hospitality Management, 30(4), 1020-1026.

Ko, J., \& Hur, S. (2014). The impacts of employee benefits, procedural justice, and managerial trustworthiness on work attitudes: Integrated understanding based on social exchange theory. Public Administration Review, 74(2), 176-187. 
Loi, R., Hang, Yue, N., \& Foley, S. (2006). Linking employees' justice perceptions to organizational commitment and intention to leave: The mediating role of perceived organizational support. Journal of Occupational \& Organizational Psychology, 79(1), 101-120.

Mayer, D. M., Aquino, K., Greenbaum, R. L., \& Kuenzi, M. (2012). Who displays ethical leadership, and why does it matter? An examination of antecedents and consequences of ethical leadership. Academy of Management Journal, 55(1), 151-171.

Mayer, D. M., Kuenzi, M., \& Greenbaum, R. L. (2010). Examining the link between ethical leadership and employee misconduct: The mediating role of ethical climate. Journal of Business Ethics, 95, 7-16.

Mayer, R. C., Davis, J. H., \& Schoorman, F. D. (1995). An integrative model of organizational trust. Academy of Management Review, 20, 709-734.

McFarlin, D. B., \& Sweeney, P. D. (1992). Distributive and procedural justice as predictors of satisfaction with personal and organizational outcomes. Academy of Management Journal, 35(3), 626-637.

Mobley, W. H., Griffeth, R. W., Hand, H. H., \& Meglino, B. M. (1979). Review and conceptual analysis of the employee turnover process, Psychological Bulletin, 86(3), 493-522.

Moorman, R. H. (1991). Relationship between organizational justice and organizational citizenship behaviors: Do fairness perceptions influence employee citizenship? Journal of Applied Psychology, 76(6), 845-855.

Mulki, J. P., Jaramillo, F., \& Locander, W. B. (2006). Effects of ethical climate and supervisory trust on salesperson's job attitudes and intentions to quit. Journal of Personal Selling \& Sales Management, 26(1), 19-26.

Mulki, J. P., Jaramillo, J. F., \& Locander, W. B. (2008). Effect of ethical climate on turnover intention: Linking attitudinal-and stress theory. Journal of Business Ethics, 78(4), 559-574.

Nadiri, H., \& Tanova, C. (2010). An investigation of the role of justice in turnover intentions, job satisfaction, and organizational citizenship behavior in hospitality industry. International Journal of Hospitality Management, 29(1), 33-41.

Netemeyer, R. G., Bearden, W. O., \& Sharma, S. (2003). Scaling procedures: Issues and applications, Thousand Oaks, CA: Sage.

Neubert, M. J., Carlson, D. S., Kacmar, K. M., Roberts, J. A., \& Chonko, L. B. (2009). The virtuous influence of ethical leadership behavior: Evidence from the field. Journal of Business Ethics, 90(2), 157-170.

Niehoff, B. P., \& Moorman, R. H. (1993). Justice as a mediator of the relationship between methods of monitoring and organizational citizenship behavior. Academy of Management journal, 36(3), 527-556.

Omar, N., \& Ahmad, Z. (2014). The Relationship among ethical climate, job satisfaction, organizational commitment, and external auditor's turnover intention. Journal of Modern Accounting \& Auditing, 10(2), 164-181.

Palanski, M., Avey, J. B., \& Jiraporn, N. (2014). The effects of ethical leadership and abusive supervision on job search behaviors in the turnover process. Journal of Business Ethics, 121(1), 135-146.

Podsakoff, P. M., MacKenzie, S. B., Moorman, R. H., \& Fetter, R. (1990). Transformational leader behaviors and their effects on followers' trust in leader, satisfaction, and organizational citizenship behaviors. The Leadership Quarterly, 1(2), 107-142.

Ponnu, C. H., \& Chuah, C. C. (2010). Organizational commitment, organizational justice and employee turnover in Malaysia. African Journal of Business Management, 4(13), 2676-2692.

Poon, J. M. (2012). Distributive justice, procedural justice, affective commitment, and turnover intention: A mediationmoderation framework. Journal of Applied Social Psychology, 42(6), 1505-1532.

Resick, C. J., Hanges, P. J., Dickson, M. W., \&Mitchelson, J. K. (2006). Cross-cultural examination of the endorsement of ethical leadership. Journal of Business Ethics, 63, 345-359.

Rich, G. A. (1997). The sales manager as a role model: Effects on trust, job satisfaction, and performance of salespeople. Journal of the Academy of Marketing Science, 25(4), 319-328.

Schwepker, C. H. Jr. (2001). Ethical climate's relationship to job satisfaction, organizational commitment, and turnover intention in the salesforce. Journal of Business Research, 54, 39- 52.

Shin, Y. (2012). CEO ethical leadership, ethical climate, climate strength, and collective organizational citizenship behavior. Journal of Business Ethics, 108(3), 299-312.

Stewart, R., Volpone, S. D., Avery, D. R., \& McKay, P. (2011). You support diversity, but are you ethical? Examining the interactive effects of diversity and ethical climate perceptions on turnover intentions. Journal of Business Ethics, 100(4), 581-593.

Toor, S. R., \& Ofori, G. (2009). Ethical leadership: Examining the relationships with full range leadership model, employee outcomes, and organizational culture. Business Ethics, 90, 533-547.

Ulrich, C., O’Donnell, P., Taylor, C., Farrar, A., Danis, M., \& Grady, C. (2007). Ethical climate, ethics stress, and the job satisfaction of nurses and social workers in the United States. Social Science \& Medicine, 65(8), 1708-1719. 
Van den Akker, L., Heres, L., Lasthuizen, K., \& Six, F. (2009). Ethical leadership and trust: It's all about meeting expectations. International Journal of Leadership Studies, 5(2), 102-122.

Victor, B., \& Cullen, J. B. (1988). The organizational bases of ethical work climates, Administrative Science Quarterly, 33(1), $101-125$.

Walumbwa, F. O., \& Schaubroeck, J. (2009). Leader personality traits and employee voice behavior: Mediating roles of ethical leadership and work group psychological safety. Journal of Applied Psychology, 94(5), 1275-1286

Walumbwa, F. O., Mayer, D. M., Wang, P., Wang, H., Workman, K., \& Christensen, A. L. (2011). Linking ethical leadership to employee performance: The roles of leader-member exchange, self-efficacy, and organizational identification. Organizational Behavior\& Human Decision Processes, 115(2), 204-213.

Wimbush, J. C., \& Shepard, J. M. (1994). Toward an understanding of ethical climate: Its relationship to ethical behavior and supervisory influence. Journal of Business Ethics, 13(8), 637-647.

Zehir, C., Müceldili, B., Altindağ, E., Şehitoğlu, Y., \& Zehir, S. (2014). Charismatic leadership and organizational citizenship behavior: The mediating role of ethical climate. Social Behavior \& Personality: An International Journal, 42(8), 13651375 . 